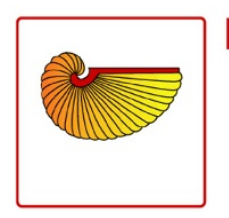

FRONTIERS IN ZOOLOGY

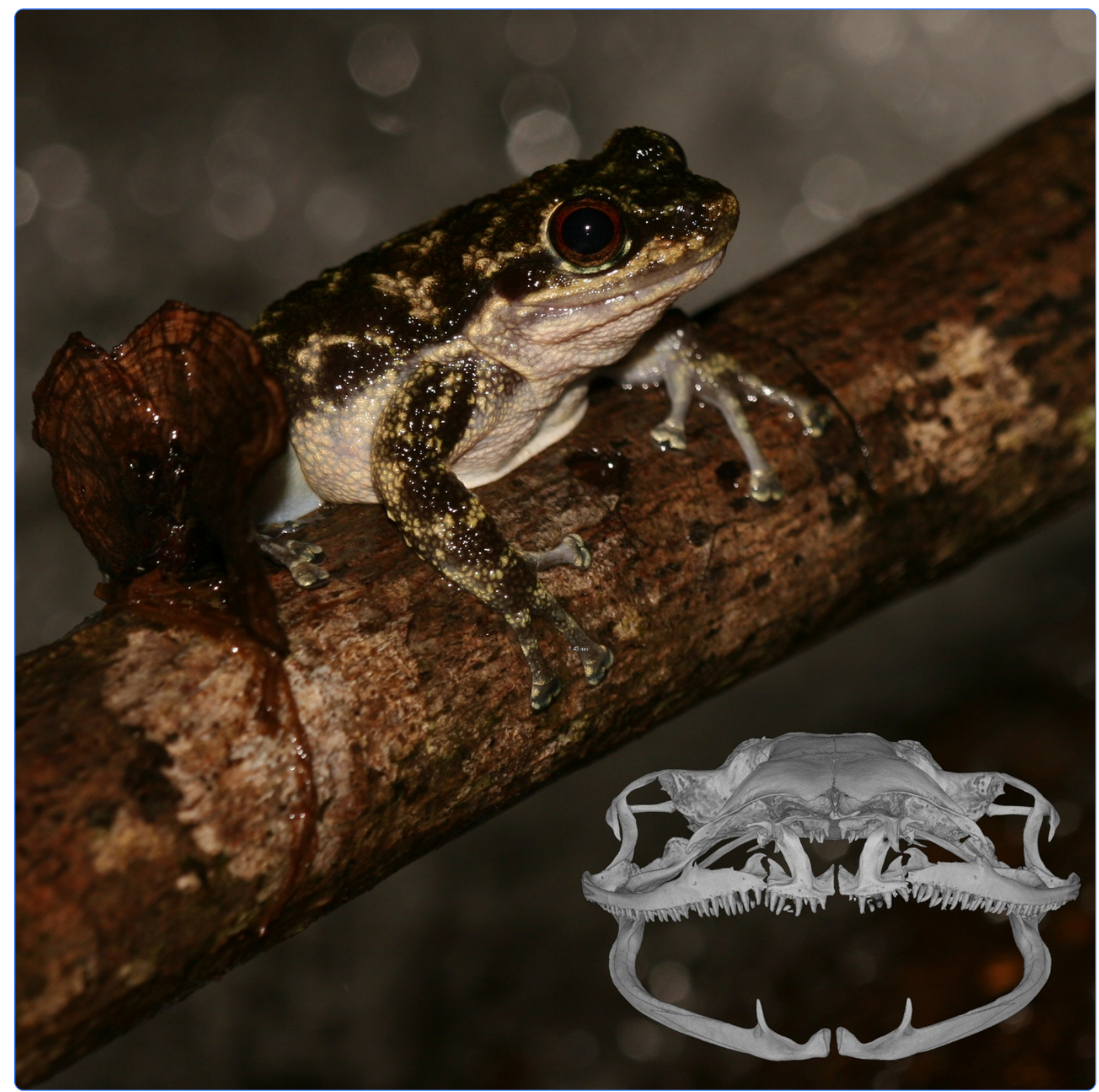

The first endemic West African vertebrate family - a new anuran family highlighting the uniqueness of the Upper Guinean biodiversity hotspot

Barej et al.

() Biomed Central 


\title{
The first endemic West African vertebrate family - a new anuran family highlighting the uniqueness of the Upper Guinean biodiversity hotspot
}

\author{
Michael F Barej ${ }^{1 *}$, Andreas Schmitz ${ }^{2}$, Rainer Günther ${ }^{1}$, Simon P Loader ${ }^{3}$, Kristin Mahlow $^{1}$ and Mark-Oliver Rödel ${ }^{1}$
}

\begin{abstract}
Background: Higher-level systematics in amphibians is relatively stable. However, recent phylogenetic studies of African torrent-frogs have uncovered high divergence in these phenotypically and ecologically similar frogs, in particular between West African torrent-frogs versus Central (Petropedetes) and East African (Arthroleptides and Ericabatrachus) lineages. Because of the considerable molecular divergence, and external morphology of the single West African torrent-frog species a new genus was erected (Odontobatrachus). In this study we aim to clarify the systematic position of West African torrent-frogs (Odontobatrachus). We determine the relationships of torrent-frogs using a multi-locus, nuclear and mitochondrial, dataset and include genera of all African and Asian ranoid families. Using micro-tomographic scanning we examine osteology and external morphological features of West African torrent-frogs to compare them with other ranoids.

Results: Our analyses reveal Petropedetidae (Arthroleptides, Ericabatrachus, Petropedetes) as the sister taxon of the Pyxicephalidae. The phylogenetic position of Odontobatrachus is clearly outside Petropedetidae, and not closely related to any other ranoid family. According to our time-tree estimation Odontobatrachus has been separated from other frog lineages since the Cretaceous (90.1 Ma; confidence interval: 84.2-97.1 Ma). Along with this molecular evidence, osteological and external diagnostic characters recognize West African torrent-frogs as distinct from other ranoids and provide strong support for the necessity of the recognition of a new family of frogs. This is the only endemic vertebrate family occurring in the Upper Guinea biodiversity hotspot.

Conclusion: Based on molecular and morphological distinctiveness, the West African torrent-frog Odontobatrachus natator is allocated to a newly described anuran family. The discovery of an endemic vertebrate family in West Africa highlights the Upper Guinean forests as an outstanding, but highly endangered biodiversity hotspot.
\end{abstract}

Keywords: Amphibia, Anura, Ranoidae, Natatanura, Odontobatrachidae fam. nov., Petropedetidae, Biodiversity hotspot, Higher level systematics, Molecular phylogeny, Osteology, West Africa

\section{Background}

The availability of large-scale phylogenies in recent years has focused attention on higher-level phylogenetic relationships in amphibians [1-7]. Frost et al. [1] introduced almost 30 higher level taxa (above family level) in anuran systematics and one additional caecilian family (Chikilidae) was recently described from India [8]. However, in the course of major phylogenetic studies two families described by Frost et al. [1] (Cryptobatrachidae, Thoropidae)

\footnotetext{
* Correspondence: michael@barej.de

${ }^{1}$ Museum für Naturkunde, Leibniz Institute for Research on Evolution and Biodiversity, Invalidenstrasse 43, D-10115 Berlin, Germany

Full list of author information is available at the end of the article
}

have been subsequently recognized as synonyms $[9,10]$. For anurans, with the exception of the discovery of the enigmatic burrowing frog Nasikabatrachus sahyadrensis (Nasikabatrachidae) from India [11], the recognition of new families in the last two decades have referred mainly to rearrangements, reassessments of subfamilies or splits of speciose genera, which have revealed the appropriate taxonomic placement of taxa $[1,9,12,13]$. So despite some nomenclatural modifications and a single exceptional finding (see above), large-scale molecular data did not make significant modifications to family level classification of anurans.

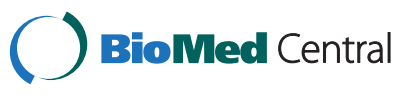

(c) 2014 Barej et al.; licensee BioMed Central Ltd. This is an Open Access article distributed under the terms of the Creative Commons Attribution License (http://creativecommons.org/licenses/by/2.0), which permits unrestricted use, distribution, and reproduction in any medium, provided the original work is properly cited. The Creative Commons Public Domain Dedication waiver (http://creativecommons.org/publicdomain/zero/1.0/) applies to the data made available in this article, unless otherwise stated. 
In the course of a phylogenetic study of sub-Saharan torrent-frogs, previously considered to be integral part of a single genus (Petropedetes Reichenow, 1874), the West African species (P. natator) was shown to be highly divergent [14]. Barej et al. [14] recovered three distinct lineages, all having distinct geographic distributions. Based on molecular and morphological differences these authors consequently described the new genus Odontobatrachus, endemic to Guinea, Sierra Leone, Liberia and Ivory Coast. The genus description was based on a number of morphological synapomorphies and a deep molecular divergence of Odontobatrachus from Central African Petropedetes and East African Arthroleptides [14]. Surprisingly, Odontobatrachus was placed outside the family Petropedetidae, challenging the monophyly of this family. It also could not be assigned to any of the other groups sampled in this study [14]. We aim at resolving the higher-level phylogenetic relationships of the genus Odontobatrachus by including molecular samples of representatives of all African and Asian ranoids. Furthermore, using micro-tomographic scanning and staining techniques, we examine the osteological and external morphological features to compare Odontobatrachus with other ranoid families.

\section{Results and discussion}

Combined analyses [a total of $3474 \mathrm{bp}$ ] of 3 mitochondrial [12S, 16S, cytb: $1472 \mathrm{bp}]$ and 3 nuclear genes [SIA, rag1, BDNF: 2002 bp] resulted in a topology consistent with recent large-scale phylogenetic studies [1,3,7]. Both Maximum Likelihood (ML) and Bayesian Inference (BI) revealed two major clades in the superfamily Ranoidea (Figure 1). The first clade consisted of the sub-Saharan families Hyperoliidae, Arthroleptidae, Hemisotidae and Brevicipitidae (in former studies referred to Afrobatrachia sensu Frost et al. [1], Arthroleptoidea sensu van der Meijden et al. [15] or Brevicipitoidea sensu Zhang et al. [7]), and the globally distributed family Microhylidae. We follow the argumentation of [7] concerning the priority of Brevicipitoidea Bonaparte, 1850, over Arthroleptoidea [16] and Afrobatrachia [1]. This major clade is consistent with current phylogenies $[1,3,7,17]$. Brevicipitoidea + Microhyloidea form a sister group to all other families in the second major clade (epifamily Ranoidae sensu van der Meijden et al. [15]). Our phylogenetic analyses placed the genus Odontobatrachus with strong support in the epifamily Ranoidae within the superfamily Ranoidea. With the exception of the families Mantellidae and Petropedetidae, all included neobatrachian families containing more than one representative (on species or genus level) showed maximum support in $\mathrm{BI}$ and $\mathrm{ML}$ (Mantellidae: $\mathrm{BS}=96, \mathrm{PP}=1.00$; Petropedetidae: discussed below). While relationships in the Brevicipitoidea + Microhylidae were well resolved, basal nodes in the Ranoidae remained unresolved in both analyses, forming a large polytomy with a single exception (Petropedetidae + Pyxicephalidae). Only Zhang et al. [7] have shown in their mitogenomic study moderate support values for family level relationships within Ranoidae. African torrent-frogs of the genera Arthroleptides and Petropedetes formed a maximally supported clade $(\mathrm{BS}=100, \mathrm{PP}=1.00)$ and together with the Ethiopian monotypic and endemic genus Ericabatrachus they represent the family Petropedetidae (BS $=93, \mathrm{PP}=1.00)$. Our analyses revealed strong support for Petropedetidae as the sister taxon to the family Pyxicephalidae (Aubria, Pyxicephalus), grouped in the Pyxicephaloidea sensu Frost et al. [1]. However, Frost et al. [1] also included Conraua and Indirana in their family Petropedetidae, both now being placed in distinct families [3]. The genus Odontobatrachus was positioned clearly outside the clade of Pyxicephalidae + Petropedetidae. A close relationship of Odontobatrachus with the pyxicephalid subfamily Cacosterninae was previously rejected by Barej et al. [14], and the inclusion of a second representative of the subfamily Pyxicephalinae supported this result. Additional analyses with constrained topologies placing Odontobatrachus sister to the families Pyxicephalidae and Petropedetidae (Ericabatrachus, Arthroleptides, Petropedetes) or within the family Petropedetidae (as the sister taxon to a clade consisting of Arthroleptides + Petropedetes or sister to any of the three genera respectively) were clearly rejected (Additional file 1: 1.3). Odontobatrachus could not be clearly assigned to any family within the Ranoidae. Bayesian analyses indicate a weakly supported sister relationship of Odontobatrachus to the family Dicroglossidae $(\mathrm{PP}=0.69)$. ML analyses weakly resolved (BS $<30$, not shown) Odontobatrachus as sister group to the Phrynobatrachidae. Dicroglossidae are known from a single species in sub-Saharan savannahs, otherwise being species rich on the Arabian Peninsula, the Indian subcontinent and Asia [18-21]. Phrynobatrachidae is found across sub-Saharan Africa [22]. Odontobatrachus is shown to be separated from all clades by a deep branch, forming a distinct and highly supported lineage (Figure 1).

Recent large-scale phylogenies [1,3,7] did not include Odontobatrachus natator. In these analyses, African torrent-frogs were represented by Central and East African taxa, and based on the assumption that Odontobatrachus natator is a petropedetid, the species has been placed in the family Petropedetidae. Scott [23] included O. natator in her simultaneous analyses of molecular and morphological data. However, only morphological data of $O$. natator was available to Scott [23], and this dataset did not place the West African taxon outside the genus Petropedetes. In contrast, our molecular results clearly deviate from this conclusion with West African torrent-frogs Odontobatrachus natator placed outside the family Petropedetidae. The distinctiveness of Odontobatrachus natator is 

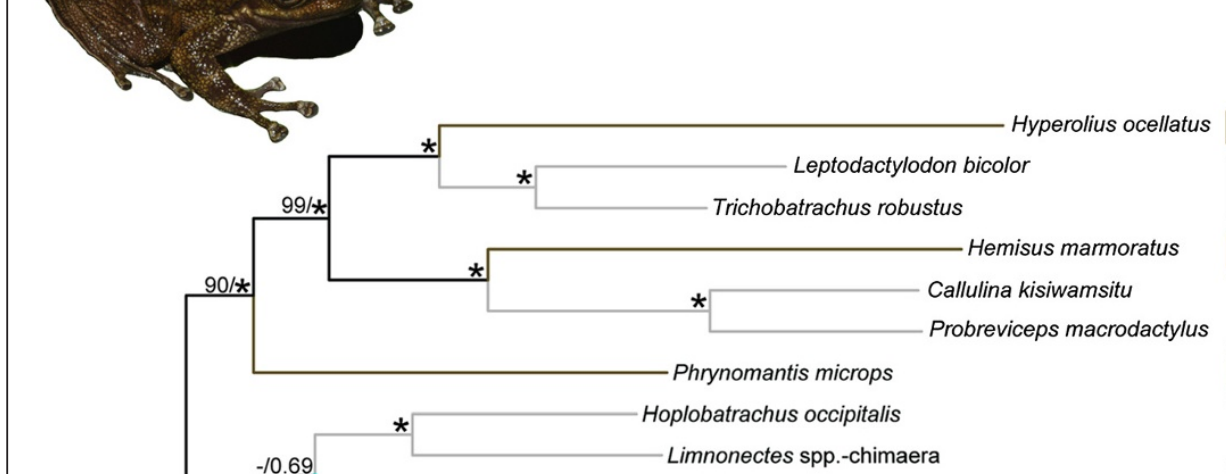

Arthroleptidae

| Hemisotidae

Brevicipitidae

| Microhylidae

Dicroglossidae

Odontobatrachidae

fam. nov

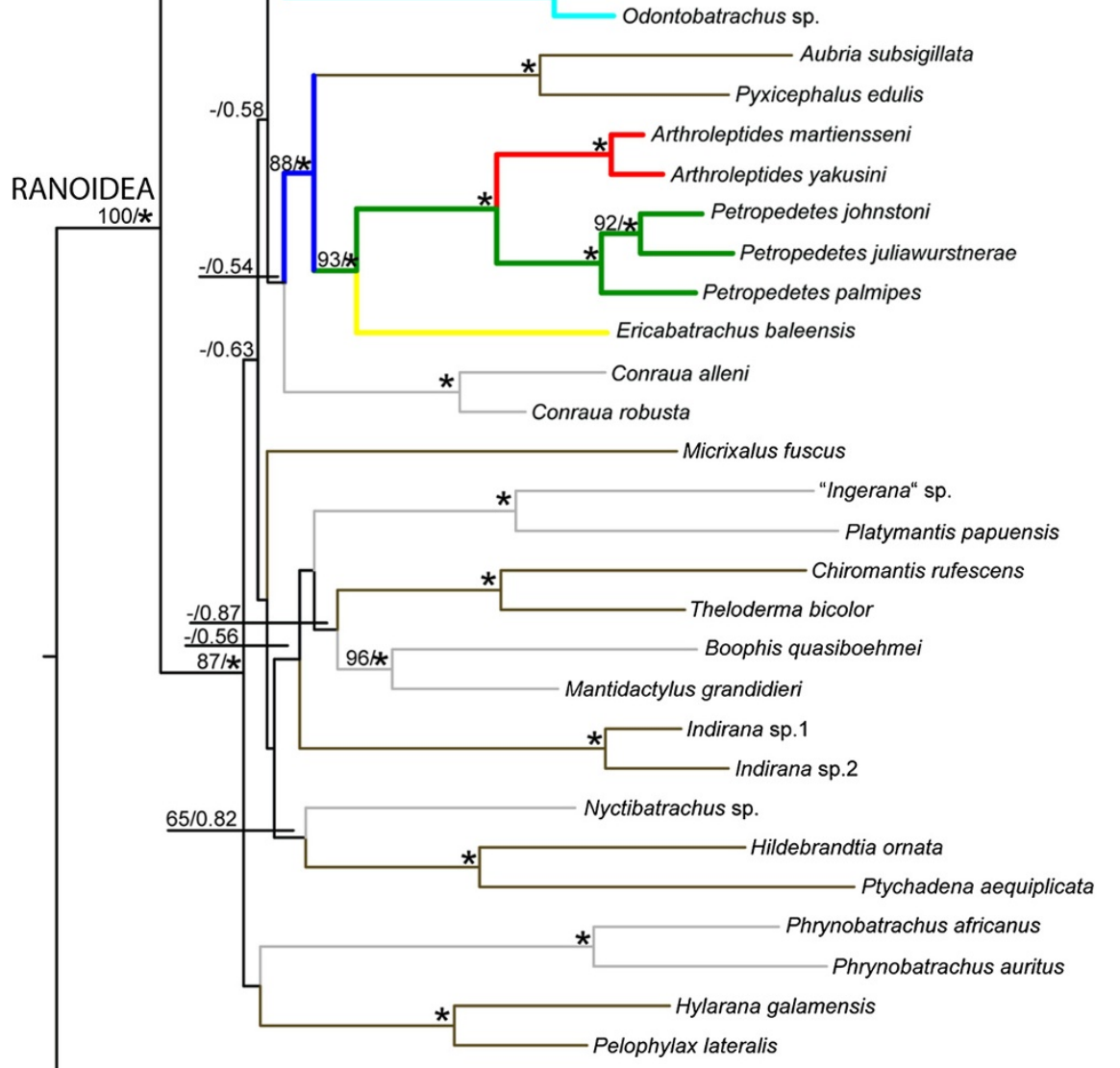

Pyxicephalidae

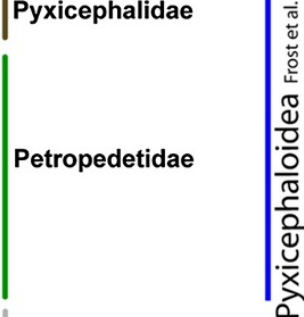

Conrauidae

| Micrixalidae

Ceratobatrachidae

Rhacophoridae

Mantellidae

Ranixalidae

Nyctibatrachidae

|Ptychadenidae

Phrynobatrachidae

Ranidae

Limnodynastidae

$[\cdots]$ Lechriodus melanopyga

Figure 1 Phylogeny of ranoid frogs. Phylogeny of ranoid frogs based on mitochondrial and nuclear data. Numbers along branches indicate bootstrap values as obtained using RAxML 7.0.4 and Bayesian posterior probabilities. Asterisks point to maximum support under both methods (ML: 100/PP: 1.00). Colour codes reflect distinct lineages of African torrent-frogs Petropedetidae (green = Petropedetes, Central Africa; red = Arthroleptides, East Africa; yellow = Ericabatrachus, Ethiopia) and West African torrent-frogs Odontobatrachidae fam. nov. (turquoise= Odontobatrachus, West Africa). 
also supported by various osteological characters (see Additional file 1: 2.2).

Our molecular time scale estimates the split of Odontobatrachus in the Cretaceous (90.1 Ma; confidence interval: 84.2-97.1 Ma; see Additional file 1: 1.2). The dates in our timescale are also temporally comparable with other major splits within the epifamily Ranoidae that are recognized at the family level rank in anuran classification [24,25]. Although, there is a lack of resolution in the basal nodes among African and Asian ranids our dating results supports the high distinctiveness of the West African torrent-frogs.

Geographical events that may support a historical scenario of long-term isolation of the West African area, as suggested by Odontobatrachus, are known from the literature. From the late Jurassic/Early Cretaceous onwards rifting of the proto-South Atlantic started and this was accompanied with development of rift systems in West and Central Africa [26]. At the same time, climate warming (peaking in the Upper Cretaceous) led to transgressions entering local basins [27] and as large parts of the continental shelf were flooded, only temporary land bridges connected the West African craton with Central Africa [28]. At the same time vegetation changed and closed canopy forests arose [29-32]. It can be therefore speculated that the West African torrent-frogs might have evolved in a geographically isolated area during ongoing vegetation changes, explaining the restricted distribution of this lineage. Other scenarios for example, extinction in other biogeographic regions of a formerly more widespread Odontobatrachus, with remaining extant lineages in West Africa, are possible but seem less likely.

In summary, despite weakly resolved basal relationships of Odontobatrachus, our results clearly support the distinctiveness of West African torrent-frogs in relation to all other families of the higher taxon Natatanura or Ranoidae (Figure 1). The problem of insufficient taxon sampling as a cause of long branches is known [33], however, our taxon sampling was relatively complete. The relative and absolute branch lengths of Odontobatrachus compared to its tentatively assigned nearest sister group correspond to those differences exhibited between other Ranoidae families in our analyses, and supports the distinct status of West African torrentfrogs Odontobatrachus.

Taxonomic changes, as proposed in our study, need to be carefully assessed in order to sustain stability of classifications. Vences et al. [34] proposed criteria for the recognition of (higher level) taxa (but see [35]). Most important criteria sensu [34] are: (i) monophyly, (ii) clade stability and (iii) phenotypic diagnosability. We demonstrate that all these aspects are applicable in the case of the West African torrent-frogs Odontobatrachus.
As (i) the case concerns a single genus (with currently one described species and potentially additional taxa), (ii) recognized to be distinct by a phylogenetic approach using optimization methods with a dense taxon and genetic sampling, and (iii) morphological differentiation from all other families [see below]. A detailed differentiation between the morphologically most similar petropedetid genera is given in the Additional file 1: 2.2. Consequently, we place the West African torrent-frogs Odontobatrachus in an own, new family, described below.

Amphibia Linnaeus, 1758

Lissamphibia Haeckel, 1866

Anura Rafinesque, 1815

Neobatrachia Reig, 1958

Odontobatrachidae fam. nov.

Type genus: Odontobatrachus Barej, Rödel, Loader \& Schmitz, 2014

Type species: Petropedetes natator Boulenger, 1905

\section{Diagnosis}

The new family is distinguished from all other families within the Ranoidea on the basis of molecular characters (see Figure 1) and the following combination of morphological characters (see also Additional file 1: 2).

\section{Osteological characters \\ Skull}

Nasals large, rectangular, in median contact; nasals overlapping sphenethmoid; ventral sphenethmoid with considerable forward extension; anterior ramus of pterygoid not reaching neopalatines and planum orbitale; posterior process of vomer connected to main mass of vomer, vomerine teeth present; premaxillary and maxillary teeth distinct, curved backwards and pointed (Figure 2); tusk-like odontoid on lower mandible; zygomatic ramus longer than otic ramus.

\section{Pectoral girdle}

Base of omosternum convex; medial edges of coracoids not overlapping; posterior edge of sternum wide and weakly serrated; metasternum short and hourglass shaped, with broad bony stylus; clavicle thickness approximately equal along entire length.

\section{Axial skeleton}

Centrum of presacral vertebra VIII rather amphicoelous; metacarpal of digit II in breeding males not enlarged and spike-like; shape of terminal phalanges $\mathrm{T}$ - to slightly Y-shaped on hand and on foot.

\section{Hyolaryngeal apparatus}

Hyoid plate wider than long; hyale without a free flange towards jaw, hyale with a small and hooked anterior 

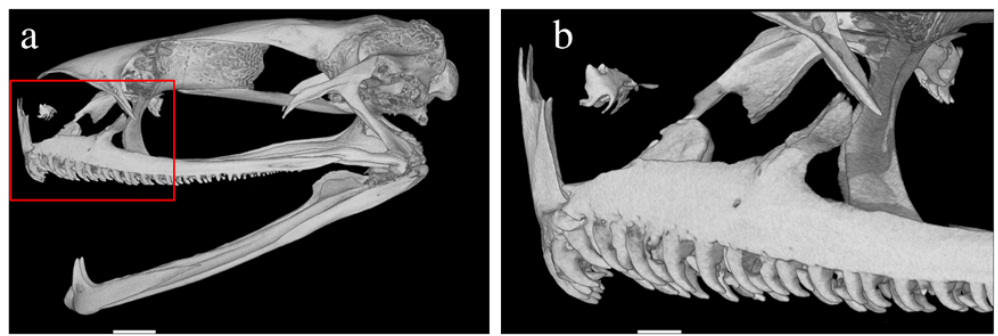

Figure 2 CT-scan of Odontobatrachus skull. Computer tomographic scan in lateral view of Odontobatrachus natator skull (ZMB 78203) a: lateral view of left side, lower jaw virtually rotated to open the mouth, red square defines close-up shown in b; scale bar $=1.5 \mathrm{~mm}$; $\mathbf{b}$ : close up of the anterior part of the maxilla; scale bar $=0.5 \mathrm{~mm}$. The images highlighting the tusk-like odontoids on the lower mandible as well as curved and pointed pre- and maxillary teeth; skull virtually isolated from the remaining skeleton.

process; hyoglossal sinus deeper than anterior border of base of anterolateral processes; anterolateral processes T-shaped with a broad base, the posterolateral processes long, reaching up to the middle of the posteromedial processes; distance between anterior edges of posteromedial processes less than one time of their width; small cartilaginous bridge between the enlarged anterior ends of the posteromedial processes; calcifications or ossifications only present in posteromedial processes.

\section{External morphology}

Tympanum indistinct, smaller than eye diameter; skin granular with enlarged ridges (roundish to elongate); extensive webbing; males with pair of external vocal sacs; positioned ventrolaterally; nuptial excrescences velvety in breeding males; femoral glands present in males only.

\section{Tadpole morphology}

Flattened body shape, sucker-like mouthparts with enlarged labials.

\section{Differential diagnosis}

A combination of the above mentioned characters distinguishes the new family from remaining taxa within the superfamily Ranoidea. However, a few characters are sufficient to exclude most of them (based on [23,36-42]: Osteology: maxillaries with teeth (absent in Brevicipitidae, Microhylidae); vomerine teeth present (absent in Micrixalidae); presence of mandibular tusks (present otherwise only in Ceratobatrachidae, Dicroglossidae, Nyctibatrachidae, Phrynobatrachidae, Pyxicephalidae, Ranixalidae); zygomatic ramus longer than otic ramus (shorter in Mantellidae, Petropedetidae); crista parotica cartilaginous (mineralized in Conrauidae, Dicroglossidae, Pyxicephalidae); terminal phalanges $\mathrm{Y}$ - to T-shaped (blunt or pointed in Hemisotidae, Dicroglossidae, curved in Ptychadenidae); external morphology: medium to large sized frogs reaching $65 \mathrm{~mm}$ snout-vent length $(<30 \mathrm{~mm}$ in Micrixalidae); dorsal skin granular with short dorsal and dorsolateral glandular ridges (skin smooth with dorsolateral glandular ridge in Micrixalidae); tympanum indistinct (distinct in Ranixalidae); presence of femoral glands (shared with Mantellidae, Nyctibatrachidae, Petropedetidae, Phrynobatrachidae, Pyxicephalidae, Ranixalidae); absence of gular gland (present in Hyperoliidae); absence of lateral line system (present in Conrauidae, Nyctibatrachidae); hyoid with long posterolateral process (short or absent in Arthroleptidae, Hyperoliidae, Mantellidae); presence of nuptial pads (absent in Nyctibatrachidae).

The morphologically most similar family Petropedetidae can be differentiated from Odontobatrachidae fam. nov. by the following morphological characters: presence of tusk-like odontoids on mandible (absent in Petropedetidae), presence of lateral vocal sacs in males (absent or median in Petropedetidae). A detailed differential diagnosis to Central and East African torrent frogs (Petropedetes and Arthroleptides) including an osteological differentiation is provided in Additional file 1: 2.

\section{Phylogenetic definition}

The new family comprises all anurans which are more closely related to Odontobatrachus natator than to members of other ranoid families. Current content: one genus, Odontobatrachus.

\section{Distribution}

The single included genus is known from the Upper Guinean forests in Guinea [43-47], Sierra Leone [48,49], Liberia [50], and western Ivory Coast [51], where frogs usually occur close to streams with strong currents and cascades or rapids.

\section{Diversity}

At present a single species is described, Odontobatrachus natator (Boulenger, 1905). However, Barej et al. [14] already recognized a higher diversity in this lineage and a more detailed taxonomic analysis of the family throughout the distribution range in the Upper Guinea forests is in preparation (M.F. Barej et al. unpubl. data). 


\section{Etymology}

The name refers to the Greek words ódoúc (odous = tooth, genitive: odóntos) and $\beta \alpha \tau \rho \alpha \chi o \sigma$ (batrachos $=$ frog) and points to the exceptionally long maxillary teeth and large tusks on lower jaws in these frogs (Figure 2).

Remark: In accordance with article 8.5 of the International code of Zoological Nomenclature (International Commission on Zoological Nomenclature [52]) the present publication (LSID: urn:lsid:zoobank.org:pub:DFB71831-37 B0-4292-8193-74C8045CD35B) and nomenclatural act (LSID: urn:lsid:zoobank.org:act:464214AA-FB13-4626-B0 4E-55DB0DE94B2A) have been registered in ZooBank.

\section{Hotspot West Africa}

'West African Forests' have been recognized as one of the major biodiversity hotspots on global scale [53,54]. This hotspot comprises two parts, the "Upper" and "Lower Guinea" forests. Only recently the West African amphibian fauna was confirmed to be distinct from those of the Central African parts of the Guineo-Congolian forest block [55]. Despite a high number of endemic amphibians (especially forest species), the West African biodiversity hotspot [55] comprises only four endemic anuran genera (Morerella, Nimbaphrynoides, Odontobatrachus, Pseudhymenochirus) $[14,39,56,57]$, the lowest number of endemic genera compared to the other biogeographic realms of the African continent (Central Africa: 17; eastern Africa 13, southern Africa 11; Additional file 1: 3). West African endemics are known from various different taxonomic groups, although diversity in many of them is still not completely understood (e.g. bats [58,59], primates [60]; plants [61-63], fresh water fish [64], birds, amphibians and mammals $[65,66])$. However, among terrestrial vertebrates in western Africa, there are no endemic bird genera, only a single endemic skink genus (Cophoscincopus) and six endemic mammal genera, including the pygmy hippopotamus and the red colobus (Hexaprotodon, Procolobus, Liberiictis, Micropotamogale, Leimacomys, Dephomys [67-69]). So far no endemic vertebrate taxon, higher than genus level, is known for the Upper Guinea forests of West Africa.

West African torrent-frogs have for a long time been assumed to form a distinct sub-Saharan lineage (Amiet in Perret [70]), although they cover similar ecological niches as Central and East African torrent-frogs [71-74]. More than a century after the species description [48], West African torrent-frogs are now assigned to a distinct family, Odontobatrachidae fam. nov., based on molecular and morphological characters. The placement of these frogs outside the Petropedetidae [14] or any other ranoid family, as shown here, provides important evidence that a deep diverging endemic lineage occurs in West Africa. Although Western Africa has the lowest number of anuran genera (4 endemics and 27 in total), all biogeographical areas in Africa show similar numbers of families (East Africa $=15$, West, Central, South Africa $=$ 14; data extracted from [75]; Additional file 1: 3). Interestingly however, only South Africa and West Africa have an endemic anuran family (namely Heleophrynidae in South Africa [76]).

Both endemic families share similarities in being relatively species poor relative to their age compared to other anuran families [25,76-80]. Whether the distinction of endemic families and their diversity in western and southern Africa reflects something about the specific biogeographical history of these areas, or our incomplete understanding of African amphibians in general, is difficult to assess. Despite this uncertainty, the description of a family with a highly restricted distribution is of biogeographical and conservation significance. Conservation of genetic diversity [81-83], as well as species richness is increasingly seen as an important consideration [84-88]. Therefore, the conservation of West African forests for amphibians is of high priority and highlights more broadly the biological importance of this area. This is particularly necessary given conservation of Upper Guinean forest habitats is generally poor, and forest cover is rapidly shrinking [89], with negative consequences for many different taxonomic groups [90-94]; but see [95] in an area rich in endemic species [53].

Despite a burst of taxonomic activity in the description of Upper Guinean amphibians, with more than a dozen described taxa since the year 2000 [1] and many additional species awaiting description (Rödel et al. unpubl data), the finding of a distinct evolutionary anuran lineage reflects how incomplete our knowledge within an apparently wellstudied part of this continent really is. The extraordinary finding of a new vertebrate family (Amphibia, Anura, Odontobatrachidae fam. nov.), endemic to western Africa highlights the peculiarity of the Upper Guinea hotspot.

\section{Conclusion}

West African torrent-frogs have been recently recognized as a distinct genus [14]. This study demonstrates the distinctiveness of this lineage among all currently known families in the Ranoidea clade. Preliminary dating points to an origin of the lineage in the Cretaceous, a period of high diversification of family lineages in Ranoidea [25]. Molecular results distinguish the lineage comprising West African torrent-frogs from all known Ranoidea families. A comparison of osteological characters of this lineage with torrent-frogs from Central and East Africa, family Petropedetidae, further supports its distinctiveness. Consequently, a new family, Odontobatrachidae fam. nov., is described for West African torrent-frogs. The genus Odontobatrachus is monotypic but undescribed species have been identified and their description is pending [14]. Present findings of an endemic frog family in West Africa 
reflect the importance of this biodiversity hotspot, as South Africa is the only other African region with an endemic anuran family.

\section{Methods}

Taxon sampling and phylogenetics

Presented data comprise representatives of all families currently grouped in the superfamily Ranoidea $[3,7,15,96]$. More specifically, our focus was on the taxon Natatanura $[25,97,98]$ or Ranoidae $[7,15]$. Included taxa are members of the families (respective geographic origin: Africa $=\mathrm{AF}$, Asia = AS, Madagascar = MG): Arthroleptidae (AF), Brevicipitidae (AF), Ceratobatrachidae (AS), Conrauidae (AF), Dicroglossidae (AF/AS), Hemisotidae (AF), Hyperoliidae (AF), Mantellidae (MG), Micrixalidae (AS), Microhylidae (AF), Nyctibatrachidae (AS), Petropedetidae (AF), Phrynobatrachidae (AF), Ptychadenidae (AF), Pyxicephalidae (AF), Ranidae (AF/AS), Ranixalidae (AS), Rhacophoridae (AF/ AS), Odontobatrachus (incertae sedis sensu Barej et al. [14]; AF). The monotypic genus Ericabatrachus, not available to Barej et al. [14], has been recently demonstrated to be closely related to the African torrent-frog family Petropedetidae [99], and has been added here in order to cover the whole phylogenetic diversity of this group. A list including all voucher identifications and GenBank [100] numbers is provided in the Additional file 1: 1.1. A member of the family Limnodynastidae has been included as the single outgroup taxon in the analysis. The family Limnodynastidae, present in Australia and New Guinea, is also part of the Neobatrachia and therein is assigned to the Myobatrachoidea (sensu Bossuyt \& Roelants [25]).

\section{Molecular analyses}

Applied methods followed [14] with regard to lab protocols and data analyses. The final data matrix consisted of three nuclear [Seven-in-Absentia (SIA: 396 bp), Recombination Activation gene 1 (rag1: $930 \mathrm{bp}$ ) and Brainderived neurotrophic factor gene (BDNF: $676 \mathrm{bp})]$ and three mitochondrial genes [(12S rRNA: 346 bp, $16 S$ rRNA: $538 \mathrm{bp}$, cytochrome b gene $c y t b: 588 \mathrm{bp})]$. Bayesian Inference (MrBayes, version 3.21 [101]) and Maximum Likelihood (RAxML version 7.0.4 [102] using the rapid hill climbing algorithm following Stamatakis et al. [103]) were applied to access phylogenetic relationships. Bootstrap analyses (BS) with 1000 pseudoreplicates in the ML analysis were used to evaluate the relative branch support in the phylogenetic analysis. Bayesian analyses were run for 5 million generations using four chains sampling every 100 generations, with a burn-in of 1000 trees. Clades with posterior probabilities $(\mathrm{PP}) \geq 95 \%$ were considered strongly supported. Stationarity has been checked with Tracer V1.5 [104]. Seven alternative tree topologies were evaluated against our optimal tree topology using the approximately unbiased test (AU) [105] and the multiple comparisons test (SH, Shimodaira-Hasegawa test) [106] as implemented in Treefinder Version of March 2011 [107].

\section{Osteological analyses}

A i) morphological and anatomical diagnosis of the West African lineage and ii) an in-depth anatomic comparison to the externally similarly looking Petropedetes and Arthroleptides was conducted. In order to achieve this a non-destructive micro-tomographic analysis based on four West African vouchers (Odontobatrachus natator males: ZMB 78203, ZMB 78222, ZMB 78243; female: ZMB 78216) and representatives of Central and East African torrent-frogs (see Additional file 1: 2.1) was carried out. Images were generated using a Phoenix nanotom X-ray $\mid \mathrm{s}$ tube at $70-80 \mathrm{kV}$ and $90-100 \mu \mathrm{A}$ for total body scans, 90-100 kV and 90-150 $\mu \mathrm{A}$ for close-ups of the skull respectively, generating 1000 projections per scan. Effective voxel size ranged between $17-23 \mu \mathrm{m}$ for total body scans and $8-16 \mu \mathrm{m}$ for close-ups of the skull. The cone beam reconstruction was performed using the datos $\mid \mathrm{x}$ reconstruction software (GE Sensing \& Inspection Technologies $\mathrm{GMBH}$ phoenix|x-ray) and the data were visualized in VG Studio Max 2.1. To back up the validity of CT-scan interpretations, we additionally cleared and double stained ZMB 78222, according to a modified method of Dingerkus \& Uhler [108]. A complete description of osteological characters, a figure of the double stained hyolaryngeal apparatus and plates of osteological characters are provided in Additional file 1: 2.1 and 2.2.

\section{Dating estimates}

Dating was performed with the software package BEAUti and BEAST 1.7.5 [109] under the Yule Process speciation model [110,111] and the relaxed clock model [112]. Mean heights and 95\% credibility interval values for node time estimates were generated from a total of 3474 bp of coding and non-coding genes (Additional file 1: 1.2). An ultrametric tree was generated with Mesquite Version 2.75 [113] as the starting tree for Beast analyses. The following outgroup taxa were added to our dating approach, to ensure known calibration constraints on internal nodes: Latimeria, Hynobius, Andrias and Calyptocephalella (GenBank numbers see Additional file 1: 1.2).

Calibration points are based on fossil records and published review data (splits $5-10$ are based on published data by Bossuyt \& Roelants [25]): 1. split coelacanth - tetrapoda (420 Ma [114]), 2. split Anura - Caudata (230 Ma; based on fossils of Triadobatrachus [115]), 3. split hynobiid and cryptobranchid salamanders (161 Ma; based on cryptobranchid fossil [116]), 4. split Calyptocephalella and Lechriodus (min. $53 \mathrm{Ma}$; based on Calyptocephalella fossil [117]), 5. split Ranoidea - remaining Neobatrachia (161 Ma), 6. split Ranoidea - Myobatrachoidea (Limnodynastidae; 119 Ma), 7. split Microhyloidae + Brevicipitoidea - Ranoidae 
(117 Ma), 8. split Brevicipitoidea (sensu Zhang et al. [7]) Microhyloidae (102 Ma), 9. split Arthroleptidae - Hyperoliidae (87.7 Ma), 10. split Pyxicephalidae - Petropedetidae (81.1 Ma). Calibrations have been applied solely to a reduced dataset as basal relationships within the Ranoidae remain poorly or even not resolved. Included taxa refer to five outgroup taxa (Latimeria, Hynobius, Andrias, Calyptocephalella, Lechriodus), Microhylidae, Brevicipitoidea (Arthroleptidae, Brevicipitidae, Hemisotidae, Hyperoliidae) and Ranoidae (Dicroglossidae, Petropedetidae, Pyxicephalidae and the new family).

\section{Additional file}

Additional file 1: The first endemic West African vertebrate family - a new anuran family highlighting the uniqueness of the Upper Guinean biodiversity hotspot [1. Molecular analyses (GenBank numbers, molecular dating, topology test); 2. Osteological analyses (Odontobatrachus osteology, Petropedetidae vs. Odontobatrachidae fam. nov.); 3. Amphibian diversity in African realms 4. References of Additional file].

\section{Competing interests}

The authors declare that they have no competing interests.

\section{Authors' contributions}

MFB, AS, MOR designed the study. Molecular data collection was performed by MFB, AS and SPL. Analyses were carried out by MFB and AS. KM generated CT-scans and prepared respective figures. Osteological analyses were performed by RG and MFB. Data interpretation and preparation of the manuscript was done by MFB, AS, RG, MOR and SPL. The final manuscript was written by MFB. All authors read, commented on and approved the final manuscript.

\section{Acknowledgements}

We are indebted to D.C. Blackburn (CAS), W. Böhme (ZFMK), F. Bossuyt (VU Brussels), T. Hartmann (ZFMK), J. Riemann (University of Hamburg), B.L. Stuart (NCSM), I. van Bocxlaer (VU Brussels) and M. Vences (TU Braunschweig) for access to important samples. MFB got a SYNTHESYS grant (GB-TAF-1474) to examine type material of $O$. natator, the stay was supported by D. Gower (BMNH). Thanks to J. Penner (MfN), P. Wagner (ZFMK), A. Cibois (MHNG), S. Fisch-Muller (MHNG), R. Covain (MHNG) and M. Ruedi (MHNG) for fruitful discussions, advices and access to literature. We thank M. Vences and S. Lötters for their constructive criticisms which improved the manuscript. We appreciate K. Siu-Ting and colleagues who shared their Ericabatrachus results with us. H.C. Liedtke and R. Hagman (University of Basel) are thanked for assistance in the laboratory. The Swiss National Science Foundation (31003A-133067) is thanked for supporting SPL. J.Penner (MfN) provided the cover page photo.

\section{Author details}

${ }^{1}$ Museum für Naturkunde, Leibniz Institute for Research on Evolution and Biodiversity, Invalidenstrasse 43, D-10115 Berlin, Germany. ${ }^{2}$ Department of Herpetology and Ichthyology, Natural History Museum of Geneva, CP 6434, 1211 Geneva 6, Switzerland. ${ }^{3}$ Department of Environmental Sciences (Biogeography), University of Basel, Klingelbergstr. 27, Basel 4056, Switzerland.

Received: 5 November 2013 Accepted: 21 December 2013 Published: 3 February 2014

\section{References}

1. Frost DR, Grant T, Faivovich J, Bain RH, Haas A, Haddad CFB, de Sà RO, Channing A, Wilkinson M, Donnellan SC, Raxworthy CJ, Campbell JA, Blotto BL, Moler P, Drewes RC, Nussbaum RA, Lynch JD, Green DM, Wheeler WC: The amphibian tree of life. Bull Am Mus Nat Hist 2006, 297:1-370.
2. Hay JM, Ruvinsky I, Hedges SB, Maxson LR: Phylogenetic relationships of amphibian families inferred from DNA sequences of mitochondrial $12 \mathrm{~s}$ and 16s ribosomal RNA genes. Mol Biol Evol 1995, 12:928-937.

3. Pyron RA, Wiens JJ: A large-scale phylogeny of Amphibia including over 2800 species, and a revised classification of extant frogs, salamanders, and caecilians. Mol Phyl Evol 2011, 61:543-583.

4. Weisrock DW, Harmon LJ, Larson A: Resolving deep phylogenetic relationships in salamanders: Analyses of mitochondrial and nuclear genomic data. Syst Biol 2005, 54:758-777.

5. Wilkinson M, San Mauro D, Sherratt E, Gower DJ: A nine-family classification of caecilians (Amphibia: Gymnophiona). Zootaxa 2011, 2874:41-64.

6. Zhang P, Wake DB: Higher-level salamander relationships and divergence dates inferred from complete mitochondrial genomes. Mol Phyl Evol 2009, 53:492-508.

7. Zhang P, Liang D, Mao R-L, Hillis DM, Wake DB, Cannatella DC: Efficient sequencing of anuran mtDNAs and a mitogenomic exploration of the phylogeny and evolution of frogs. Mol Biol Evol 2013, 3:1899-1915.

8. Kamei RG, San Mauro D, Gower DJ, Van Bocxlaer I, Sherratt E, Thomas A, Babu S, Bossuyt F, Wilkinson M, Biju SD: Discovery of a new family of amphibians from northeast India with ancient links to Africa. Proc $R$ Soc $B$ 2012, 279:2396-2401.

9. Grant T, Frost DR, Caldwell JP, Gagliardo R, Haddad CFB, Kok PJR, Means DB, Noonan BP, Schargel WE, Wheeler WC: Phylogenetic systematics of dart-poison frogs and their relatives (Amphibia: Athesphatanura: Dendrobatidae). Bull Am Mus Nat Hist 2006, 299:1-262.

10. Guayasamin JM, Castroviejo-Fisher S, Ayarzagüena J, Trueb L, Vilà C: Phylogenetic relationships of glassfrogs (Centrolenidae) based on mitochondrial and nuclear genes. Mol Phyl Evol 2008, 48:574-595.

11. Biju SD, Bossuyt F: New frog family from India reveals an ancient biogeographical link with the Seychelles. Nature 2003, 425:711-714.

12. Hedges SB, Duellman W, Heinicke MP: New World direct-developing frogs (Anura: Terrarana): Molecular phylogeny, classification, biogeography, and conservation. Zootaxa 2008, 1737:1-182.

13. Heinicke PM, Duellman WE, Trueb L, Means DB, MacCulloch RS, Hedges BS: A new family (Anura: Terrarana) from South America and an expanded direct developing clade revealed by molecular phylogeny. Zootaxa 2009, 2211:1-35.

14. Barej MF, Rödel M-O, Loader SP, Menegon M, Gonwouo NL, Penner J, Gvoždík G, Günther R, Bell RC, Nagel P, Schmitz A: Light shines through the spindrift phylogeny of African torrent frogs (Amphibia, Anura, Petropedetidae). Mol Phyl Evol 2014, 71:261-273.

15. van der Meijden A, Vences M, Hoegg S, Meyer A: A previously unrecognized radiation of ranid frogs in Southern Africa revealed by nuclear and mitochondrial DNA sequences. Mol Phyl Evol 2005, 37:674-685.

16. Dubois A: Notes sur la classification des Ranidae (Amphibiens, Anoures). Bull Soc Linn Lyon 1992, 61:305-352.

17. de Sá RO, Streicher JW, Sekonyela R, Forlani MC, Loader SP, Greenbaum E, Richards S, Haddad CF: Molecular phylogeny of microhylid frogs (Anura: Microhylidae) with emphasis on relationships among New World genera. BMC Evol Biol 2012, 12:241.

18. Briggs $\lrcorner$, Ault $C S$ : Distribution of the genus Rana in southwestern Saudi Arabia. Herp Rev 1985, 16:72-75.

19. Inger RF: Commentary on a proposed classification of the family Ranidae. Herpetologica 1996, 52:241-246.

20. Kotaki M, Kurabayashi A, Matsui M, Kuramoto M, Hon Djong T, Sumida M: Molecular Phylogeny of the diversified frogs of genus Fejervarya (Anura: Dicroglossidae). Zool Sci 2010, 2010(27):386-395.

21. McLeod DS: Of Least Concern? Systematics of a cryptic species complex: Limnonectes kuhlii (Amphibia: Anura: Dicroglossidae). Mol Phyl Evol 2010, 56:991-1000.

22. Zimkus BM, Rödel M-O, Hillers A: Complex patterns of continental speciation: molecular phylogenetics and biogeography of sub-Saharan puddle frogs (Phrynobatrachus). Mol Phyl Evol 2010, 55:883-900.

23. Scott E: A phylogeny of ranid frogs (Anura: Ranoidea: Ranidae), based on a simultaneous analysis of morphological and molecular data. Cladistics 2005, 21:507-574.

24. Avise JC, Liu J-X: On the temporal inconsistencies of Linnean taxonomic ranks. Biol J Linn Soc 2011, 102:707-714.

25. Bossuyt F, Roelants K: Frogs and toads (Anura). In The Time-Tree of Life Edited by Hedges SB, Kumar S. New York: Oxford University Press; 2009:357-364 
26. Binks RM, Fairhead JD: A plate tectonic setting for Mesozoic rifts of West and Central Africa. Tectonophysics 1992, 213:141-151.

27. Guiraud R, Bosworth W, Thierry J, Delplanque A: Phanerozoic geological evolution of Northern and Central Africa: an overview. J Afr Earth SCi 2005, 43:83-143.

28. Scotese CR: PALEOMAP website. http://www.scotese.com.

29. Crane PR, Lidgard S: Angiosperm diversification and paleolatitudinal gradients in Cretaceous floristic diversity. Science 1989, 246:675-678

30. Davis CC, Webb CO, Wurdack KJ, Jaramillo CA, Donoghue MJ: Explosive radiation of Malpighiales supports a mid-Cretaceous origin of modern tropical rain forests. Am Nat 2005, 165:E36-E65.

31. de Bodt S, Maere S, van de Peer Y: Genome duplication and the origin of angiosperms. Trends Ecol Evol 2005, 20:591-597.

32. Lidgard S, Crane PR: Angiosperm diversification and Cretaceous floristic trends; a comparison of palynofloras and leaf macrofloras. Paleobiology 1990, 16:77-93.

33. Wiens JJ: Can incomplete taxa rescue phylogenetic analyses from long-branch attraction? Syst Biol 2005, 54:731-742.

34. Vences M, Guayasamin JM, Miralles A, de la Riva I: To name or not to name: Criteria to promote economy of change in Linnaean classification schemes. Zootaxa 2013, 3636:201-244.

35. Hedges SB: Revision shock in taxonomy. Zootaxa 2013, 3681:297-298.

36. Boulenger GA: Sur la conformation des phalangettes chez certaines grenouilles d'Afrique. C R Hebd Séances Acad Sci Paris 1917, 165:987-990.

37. Blommers-Schlösser RMA: Systematic relationships of the Mantellinae Laurent 1946 (Anura Ranoidea). Eth Ecol Evol 1991, 5:199-218.

38. Dubois A: Diagnose préliminaire d'un nouveau genre de Ranoidea (Amphibiens, Anoures) du sud de l'Inde. Alytes 1985, 4:113-118.

39. Dubois A: Miscellanea taxinomica batrachologica (I). Alytes 1987, 5:7-95.

40. Dubois A, Ohler A: A new genus for an aquatic ranid (Amphibia, Anura) from Sri Lanka. Alytes 2001, 19:81-106.

41. Kamermans $M$, Vences $M$ : Terminal phalanges in ranoid frogs: morphological diversity and evolutionary correlation with climbing habits. Alytes 2009, 26:177-152.

42. Vitt LJ, Caldwell JP: Herpetology: An Introductory Biology of Amphibians and Reptiles. 3rd edition. San Diego: Academic; 2009.

43. Böhme W: Frösche und Skinke aus dem Regenwaldgebiet Südost-Guineas, Westafrika. II. Ranidae, Hyperoliidae, Scincidae; faunistisch-ökologische Bewertung. herpetofauna 1994, 16:6-16.

44. Guibé J, Lamotte M: La réserve naturelle intégrale du Mont Nimba. XII. Batraciens (sauf Arthroleptis, Phrynobatrachus et Hyperolius). Mém Inst fond Afr noire 1958, 53:241-273.

45. Hillers A, Loua N, Rödel M-O: A preliminary assessment of the amphibians of the Fouta Djallon, Guinea, West Africa. Salamandra 2008, 44:113-122.

46. Rödel M-O, Bangoura MA: A conservation assessment of amphibians in the Forêt Classée du Pic de Fon, Simandou Range, southeastern Republic of Guinea, with the description of a new Amnirana species (Amphibia Anura Ranidae). Trop Zool 2004, 17:201-232.

47. Rödel M-O, Bangoura MA, Böhme W: The amphibians of south-eastern Republic of Guinea (Amphibia: Gymnophiona, Anura). Herpetozoa 2004, 17:99-118.

48. Boulenger GA: Descriptions of new West-African frogs of the genera Petropedetes and Bulua. Ann Mag nat Hist 1905, 15:281-283.

49. Schiøtz A: The treefrogs (Rhacophoridae) of West Africa. Spolia zool Musei Haun 1967, 25:1-346.

50. Hillers A, Rödel M-O: The amphibians of three national forests in Liberia, West Africa. Salamandra 2007, 43:1-10.

51. Rödel M-O: The amphibians of Mont Sangbé National Park, Ivory Coast. Salamandra 2003, 39:91-110

52. International Commission on Zoological Nomenclature: Amendment of articles $8,9,10,21$ and 78 of the International Code of Zoological Nomenclature to expand and refine methods of publication. Zootaxa 2012, 3450:1-7.

53. Bakarr M, Bailey B, Byler D, Ham R, Olivieri S, Omland M: From the forest to the sea: biodiversity connections from Guinea to Togo, Conservation Priority-Setting Workshop, December 1999. Washington DC: Conservation International; 2001.

54. Myers N, Mittermeier RA, Mittermeier CG, DaFonseca GAB, Kent J: Biodiversity hotspots for conservation priorities. Nature 2000, 403:853-845.

55. Penner J, Wegmann M, Hillers A, Schmidt M, Rödel M-O: A hotspot revisited a biogeographical analysis of West African amphibians. Divers Distrib 2011, 17:1077-1088
56. Chabanaud P: Contributions à l'étude de la faune herpétologique de I'Afrique occidentale. I. Note préliminaire sur les résultats d'une mission scientifique en Guinée française (1919-1920). Bull Com Ét Hist Sci Afr Occ Franç 1920, 1920:489-497.

57. Rödel M-O, Kosuch J, Grafe TU, Boistel R, Assemian NE, Kouamé N'G, Tohé B, Gourène G, Perret J-L, Henle K, Tafforeau P, Pollet N, Veith M: A new tree-frog genus and species from Ivory Coast, West Africa (Amphibia: Anura: Hyperoliidae). Zootaxa 2009, 2044:23-45.

58. Fahr J, Ebigbo NM: Rapid survey of bats (Chiroptera) in the Forêt Classée du Pic de Fon, Guinea. In A Rapid Biological Assessment of Forêt Classée du Pic de Fon, Simandou Range, South-eastern Republic of Guinea. RAP Bulletin of Biological Assessment 35. Edited by McCullough J. Washington, DC: Conservation International; 2004:69-77.

59. Monadjem A, Richards L, Taylor PJ, Stoffberg S: High diversity of pipistrelloid bats (Vespertilionidae: Hypsugo, Neoromicia, and Pipistrellus) in a West African rainforest with the description of a new species. Zool J Linn Soc 2013, 167:191-207.

60. Hacker JE, Cowlishaw G, Williams PH: Patterns of African primate diversity and their evaluation for the selection of conservation areas. Biol Conserv 1998, 84:251-262.

61. Barthlott W, Hostert A, Kier G, Küper W, Kreft H, Mutke J, Rafiqpoor D, Sommer JH: Geographic patterns of vascular plant diversity at continental to global scales. Erdkunde 2007, 61:305-315.

62. Jongkind $\mathrm{CCH}$ : Checklist of Upper Guinea forest species. Biodiversity of West African forests. In An ecological atlas of woody plant species. Edited by Poorter L, Bongers F, Kouame FN, Hawthorne WD. Wallingford: CABI Publishing; 2004:447-477.

63. Kier G, Kreft H, Lee TM, Jetz W, Ibisch PL, Nowicki C, Mutke J, Barthlott W: A global assessment of endemism and species richness across island and mainland regions. PNAS 2009, 106:9322-9327.

64. Hugueny B, Lévêque C: Freshwater fish zoogeography in West Africa: faunal similarities between river basins. Environ Biol Fishes 1994, 39:365-380

65. Conservation International. http://www.conservation.org/where/ priority_areas/hotspots/africa/Guinean-Forests-of-West-Africa.

66. Grenyer R, Orme CDL, Jackson SF, Thomas GH, Davies RG, Davies TJ, Jones KE, Olson VA, Ridgely RS, Rasmussen PC, Ding T-S, Bennett PM, Blackburn TM, Gaston KJ, Gittleman JL, Owens IPF: Global distribution and conservation of rare and threatened vertebrates. Nature 2006, 444:93-96.

67. Kingdon J: The Kingdon Field Guide to African Mammals. London: Academic; 1997.

68. Sinclair I, Ryan P: Birds of Africa south of the Sahara. Cape Town: Struik Nature; 2010.

69. Trape J-F, Trape S, Chirio L: Lézards, crocodiles et tortues d'Afrique occidentale et du Sahara. Marseille: IRD-Orstom; 2012.

70. Perret J-L: Identification de Petropedetes obscurus Ahl, 1924 (Amphibia, Phrynobatrachinae), conservés au Muséum de Berlin. Bull Soc Neuchâtel Nat 1984, 107:165-170

71. Barej MF, Rödel M-O, Gonwouo NL, Pauwels OSG, Böhme W, Schmitz A: Review of the genus Petropedetes Reichenow, 1874 in Central Africa with the description of three new species (Amphibia: Anura: Petropedetidae). Zootaxa 2010, 2340:1-49.

72. Lawson D: The reptiles and amphibians of the Korup National Park Project, Cameroon. Herp Nat Hist 1993, 1:27-90.

73. Menegon M, Bracebridge C, Owen N, Loader SP: Herpetofauna of montane areas of Tanzania. 4. Amphibians and reptiles of Mahenge Mountains, with comments on biogeography, diversity, and conservation. Fieldiana Life Earth Sci 2011, 4:103-111.

74. Sanderson IT: The amphibians of the Mamfe Division, Cameroons.-II. Ecology of the frogs. Proc Zool Soc Lond 1936, 1936:165-208.

75. Frost DR: Amphibian species of the world: an online reference. Version 5.6. 2013. http://research.amnh.org/herpetology/amphibia/index.html.

76. du Preez L, Carruthers V: A Complete Guide to the Frogs of Southern Africa. Cape Town: Struik nature; 2009

77. Minter LR, Burger M, Harrison JA, Braack HH, Bishop PJ, Kloepfer D: Atlas and Red Data Book of the Frogs of South Africa, Lesotho and Swaziland. Washington, DC: SI/MAB Series \#9. Smithsonian Institution; 2004.

78. van Dijk DE: Clades in heleophrynid Salientia. Afr J Herpetol 2008, 57:43-48.

79. San Mauro D, Vences M, Alcobendas M, Zardoya R, Meyer A: Initial diversification of living amphibians predated the breakup of Pangaea. Am Nat 2005, 165:590-599.

80. Irissari I, San Mauro D, Abascal F, Ohler A, Vences M, Zardoya R: The origin of modern frogs (Neobatrachia) was accompanied by acceleration in 
mitochondrial and nuclear substitution rates. BMC Genomics 2012, 13:e626.

81. Ennos RA, French GC, Hollingsworth PM: Conserving taxonomic complexity. Trends Ecol Evol 2005, 20:164-168.

82. Moritz C: Defining 'evolutionary significant unit' for conservation. Trends Ecol Evol 1996, 9:373-375.

83. Moritz C: Strategies to protect biological diversity and the evolutionary processes that sustain it. Syst Biol 2002, 5:238-254

84. Foord SH, Dippenaar-Schoeman AS, Stam EM: Surrogates of spider diversity, leveraging the conservation of a poorly known group in the Savanna Biome of South Africa. Biol Conserv 2013, 161:203-212.

85. Heino J: Taxonomic surrogacy, numerical resolution and responses of stream macro invertebrate communities to ecological gradients: are the inferences transferable among regions? Ecol Indic 2014, 36:186-194.

86. Heino J, Soininen J: Are higher taxa adequate surrogates for species-level assemblage patterns and species richness in stream organisms? Biol Conserv 2007, 137:78-89.

87. Kallimanis AS, Mazaris AD, Tsakanikas D, Dimopoulos P, Pantis JD, Sgardelis SP: Efficient biodiversity monitoring: which taxonomic level to study? Ecol Indic 2012, 15:100-194.

88. Timms LL, Bowden JJ, Summerville KS, Buddle CM: Does species-level resolution matter? Taxonomic sufficiency in terrestrial arthropod biodiversity studies. Insect Conserv Divers 2012, 6:453-462.

89. FAO: Global Forest Resources Assessment 2005. Progress towards Sustainable Forest Management. FAO Forestry Paper N¹47. Rome: Food and Agriculture Organization of the United Nations; 2006.

90. Beier P, van Drielen M, Kankam BO: Avifaunal collapse in West African forest fragments. Conserv Biol 2002, 16:1097-1111.

91. Brooks TM, Mittermeier RA, Mittermeier CG, da Fonseca GAB, Rylands AB, Konstant WR, Flick P, Pilgrim J, Oldfield S, Magin G, Hilton-Taylor C: Habitat loss and extinction in the hotspots of biodiversity. Conserv Biol 2002 16:909-923.

92. Ernst $R$, Linsenmair KE, Rödel MO: Diversity erosion beyond the species level: dramatic loss of functional diversity after selective logging in two tropical amphibian communities. Biol Conserv 2006, 133:143-155.

93. Hillers A, Veith M, Rödel M-O: Effects of forest fragmentation and habitat degradation on West African leaf-litter frogs. Conserv Biol 2008, 22:762-772.

94. Kofron CP, Chapman A: Deforestation and bird species composition in Liberia, West Africa. Trop Zool 1995, 8:239-256.

95. Wright SJ, Muller-Landau HC: The future of tropical forest species. Biotropica 2006, 38:287-301.

96. Wiens JJ: Global patterns of diversification and species richness in amphibians. Am Nat 2007, 170:S86-S106.

97. Roelants K, Gower DL, Wilkinson M, Loader SP, Biju SD, Guillaume K, Morlau L, Bossuyt F: Global patterns of diversification in the history of modern amphibian. PNAS 2007, 104:887-892

98. van Bocxlaer I, Roelants K, Biju SD, Nagaraju J, Bossuyt F: Late Cretaceous vicariance in Gondwanan amphibians. PLOS ONE 2006, 1:e74.

99. Siu-Ting K, Gower DJ, Pisani D, Kassahun R, Gebresenbet F, Menegon M, Mengistu AA, Saber SA, de Sa RO, Wilkinson M, Loader SP: Evolutionary relationships of the Critically Endangered frog Ericabatrachus baleensis Largen, 1991 with notes on incorporating previously unsampled taxa into large-scale phylogenetic analyses. BMC Evol Biol in press.

100. Benson DA, Cavanaugh M, Clark K, Karsch-Mizrachi I, Lipman DJ, Ostell J Sayers EW: GenBank. Nucleic Acids 2013, 41:D36-D42.

101. Huelsenbeck JP, Ronquist F: MrBAYES: Bayesian inference of phylogenetic trees. Bioinformatics 2001, 17:754-755.

102. Stamatakis A: RAxML-VI-HPC: Maximum Likelihood-based phylogenetic analyses with thousands of taxa and Mixed Models. Bioinformatics 2006, 22:2688-2690

103. Stamatakis A, Blagojevic F, Nikolopoulos D, Antonopoulos C: Exploring new search algorithms and hardware for phylogenetics: RAxML meets the IBM Cell. J VLSI Signal Process 2007, 48:271-286.

104. Rambaut A, Drummond AJ: Tracer v1.5. http://beast.bio.ed.ac.uk/Tracer.

105. Shimodaira $\mathrm{H}$ : An approximately unbiased test of phylogenetic tree selection. Syst Biol 2002, 51:492-508.

106. Shimodaira H, Hasegawa M: Multiple comparisons of log-likelihoods with applications to phylogenetic inference. Mol Biol Evol 1999, 1999(16):1114-1116.
107. Jobb G, von Haeseler A, Strimmer K: Treefinder: a powerful graphical analysis environment for molecular phylogenetics. BMC Evol Biol 2004, 4:18.

108. Dingerkus G, Uhler LD: Enzyme clearing of alcian blue stained whole small vertebrates for demonstration of cartilage. Stain Technol 1977, 52:229-232.

109. Drummond AJ, Suchard MA, Xie D, Rambaut A: Bayesian phylogenetics with BEAUti and the BEAST 1.7. Mol Biol Evol 2012, 29:1969-1973.

110. Gernhard T: The conditioned reconstructed process. J Theor Biol 2008, 253:769-778.

111. Yule GU: A Mathematical theory of evolution based on the conclusions of Dr. JC Willis. Phil Trans R Soc Lond B Biol Sci 1925, 213:21-87.

112. Drummond AJ, Ho SYW, Phillips MJ, Rambaut A: Relaxed phylogenetics and dating with confidence. PLOS Biol 2006, 4:e88.

113. Maddison WP, Maddison DR: Mesquite: a modular system for evolutionary analysis. Version 2.75. http://mesquiteproject.org.

114. Zhu M, Yu X, Ahlberg PE: A primitive sarcopterygian fish with an eyestalk. Nature 2001, 410:81-84.

115. Rage J-C, Roček Z: Redescription of Triadobatrachus massinoti (Piveteau, 1936) an anuran amphibian from the early Triassic. Paleontographica Abt A 1989, 206:1-16.

116. Gao KQ, Shubin NH: Earliest known crown-group salamanders. Nature 2003, 422:424-428.

117. Baez AM: Tertiary anurans from South America. In Amphibian Biology. Edited by Heatwole H, Carroll RL. Chipping Norton, Australia: Surrey Beatty; 2000:1388-1401.

doi:10.1186/1742-9994-11-8

Cite this article as: Barej et al:: The first endemic West African vertebrate family - a new anuran family highlighting the uniqueness of the Upper Guinean biodiversity hotspot. Frontiers in Zoology $201411: 8$

\section{Submit your next manuscript to BioMed Central and take full advantage of:}

- Convenient online submission

- Thorough peer review

- No space constraints or color figure charges

- Immediate publication on acceptance

- Inclusion in PubMed, CAS, Scopus and Google Scholar

- Research which is freely available for redistribution 